\title{
Economics of ornamental fish farming industry in Madurai District, Tamil Nadu
}

\author{
T. UMAMAHESWARI, M. RAJAKUMAR AND P. CHIDAMBARAM \\ Fisheries College and Research Institute, Tamil Nadu Fisheries University, Thoothukudi - 628008 \\ Tamil Nadu, India \\ e-mail: rajasaro@rediffmail.com
}

\begin{abstract}
India has enormous potential for the development of ornamental fish business. Although the country has conducive environmental conditions for breeding and culture of ornamental fishes, its share in export of ornamental fishes is less than $1 \%$. The present study was undertaken to address the constraints prevailing in ornamental fish farming. Study was carried out among 44 ornamental fish farms in Madurai District, Tamil Nadu by adopting random sampling technique. The selected farms were classified into small $(<0.5 \mathrm{ha})$ and medium farms $(0.5-2 \mathrm{ha})$ and the data were collected by personally interviewing the fish farmers. The study attempted to analyse the socio-economic characteristics of respondents, existing supply chain, constraints involved in ornamental fish farming, annual revenue loss due to major constraints, treatment cost and expected profit margin. Various constraints were classified as production, marketing and others and were ranked using Garrett ranking technique. Tabular and percentage analyses were used to estimate the cost of treatment, revenue loss and expected profit margin. Four types of marketing channels were observed in the study area. Disease outbreak was found to be the major constraint faced by the farmers and hence, the revenue loss was estimated for the same. The annual revenue loss was found to be higher for the small ornamental units when compared to medium farms, which showed higher profit margin than small ornamental fish farms.
\end{abstract}

Keywords: Constraints, Disease outbreak, Economics, Income, Ornamental fish farming

Indian ornamental fisheries sector is small, but it constitutes one of the vibrant sub-sectors of fisheries and aquaculture. More people are entering into this lucrative business of culturing and breeding of ornamental fishes. It is a promising alternative for employment and income generation in the domestic and export markets. Dey (2012) reported that the number of ornamental fish farms in India has increased to over 1750 , covering a water spread area of more than 170 ha and providing employment to over 20,000 people, from a mere handful in the 1970 s. A total of 100 million fish of over 130 varieties under five major groups is now being produced in the country. The overall domestic trade in this field crosses ₹ 1,000 lakhs and is reportedly growing at the rate of $20 \%$ per annum (NABARD, 2007). The share of ornamental fish exports to the total value of fisheries export has increased from $0.04 \%$ in 1991 to $0.15 \%$ in 2008 . Indian ornamental fish export registered a higher positive compound growth rate of $14.4 \%$ in terms of export value, $12.1 \%$ in terms of quantity exported and $2.1 \%$ in terms of unit value (Prathvi Rani et al., 2013). It has been estimated that India has the potential to earn about US \$ 5 billion as foreign exchange through export of ornamental fishes (Shaleesha and Stanley, 2001; Das and Sinha, 2003). With rich biotic resources, favourable climatic conditions and professional manpower availability, West Bengal has emerged as a pioneer state in ornamental fish trade in India (Mukherjee et al., 2000; Ghosh et al., 2003a, b; Singh and Ahmed, 2005). Kolkata is the main place in West Bengal where the ornamental fish trade is concentrated. About $90 \%$ of ornamental fish export of India takes place from Kolkata, followed by $8 \%$ from Mumbai and 2\% from Chennai (Sahu and Mohanty, 2000). Development of ornamental fish culture is hindered mainly by disease incidence due to parasitic, bacterial and viral infections. Many entrepreneurs hesitate to invest in this sector for want of information on the cost involved, income expected, breeding techniques and development assistance.

Madurai District in Tamil Nadu was selected for the present study, owing to its importance in the contribution to ornamental fish production. The ornamental fish units were classified into small farms (backyard) and medium farms. The sample size of ornamental fish farms was fixed as $30 \%$ for each category and hence, 26 small farms ( $0.5 \mathrm{ha})$ and 18 medium farms (0.5-2 ha) were randomly selected out of 87 small farms and 60 medium farms. A structured survey schedule was prepared, based on the objectives of the study and pre-tested by conducting a pilot survey. The farmers were interviewed individually to draw a meaningful conclusion over the factors influencing the profitability of ornamental 
fish farming. The general characteristics of farmers, average annual revenue loss due to disease incidence, treatment cost and expected profit margin were documented with respect to each farming unit.

Garrett ranking technique was employed to identify the constraints associated with the ornamental fish farming, as expressed by the ornamental fish farmer. For converting the scores assigned by the ornamental fish farmers towards the particular constraint, the Percent Position for each rank was worked out using the following formula:

$$
\text { Percent Position }=\frac{100(\mathrm{Rij}-0.05)}{\mathrm{Nj}}
$$

where, $\mathrm{Rij}=$ Rank given for the $\mathrm{i}^{\text {th }}$ constraint by $\mathrm{j}^{\text {th }}$ individual, $\mathrm{Nj}=$ Number of constraints ranked by $\mathrm{j}^{\text {th }}$ individual,

By referring to Garrett's table, the Percent Positions were converted into scores. The scores of various respondents were added and the mean values were calculated and were arranged in descending order. The factor with the highest mean value was considered to be the most important, followed by second, third and so on.

Simple tools of analysis like percentage analysis were used in the study. Tabular analysis of costs and returns was made to estimate the economics of aquariculture and to analyse the data. The expected profit margin and the revenue loss due to disease were calculated using the formulae as given below:

$\begin{aligned} \text { Expected profit margin }= & \underset{\text { Total cost }}{(\text { Expected returns }}+\text { Total returns })- \\ & \text { Total }\end{aligned}$

Revenue loss due to disease $=$ Expected profit margin Actual profit

The 44 fish farmers were interviewed for collecting data regarding their age, experience in ornamental fish farming, educational status, occupational status and farm size. It was found that about $38 \%$ of the small farmers and $39 \%$ of medium farmers were aged above 40 years. About $46 \%$ of small farmers and $50 \%$ of medium farmers had 6-10 years of experience in ornamental fish culture activities. All the farmers were literate. While $62 \%$ of the small farmers had ornamental fish culture as their primary occupation, $56 \%$ of medium farmers had ornamental fish culture as their primary income source. The average farm size was 0.42 ha and 1.40 ha for small and medium farms, respectively.

In Madurai District, the following four types of marketing channels were observed among the respondent farmers, in which Channel I was followed more frequently among small and medium ornamental fish farmers.
Channel I $\quad:$ Producer $\rightarrow$ Retailer $\rightarrow$ Consumer

Channel II : Producer cum Wholesaler $\rightarrow$ Retailer $\rightarrow$ Consumer

Channel III : Producer cum Rearer $\rightarrow$ Retailer $\rightarrow$ Consumer

Channel IV $:$ Producer $\rightarrow$ Wholesaler $\rightarrow$ Retailer $\rightarrow$ Consumer

Ranking of constraints faced during ornamental fish culture by Garrett Ranking Technique

The constraints ranked by small and medium farmers were converted to scores and the order of priority with reference to production, marketing and other constraints are furnished in Tables 1, 2 and 3, respectively. It could be inferred from the Table 1 that disease losses due to environmental factors and poor management practices were the most prominent problems associated with ornamental fish culture and these occupied the first and second position with a mean score of 74.19 and 75.94 for small and 69.46 and 67.78 for medium farms, respectively. This was followed by insufficient credit facility from institutional sources, absence of technically skilled personnel and labour and risks in breeding egg layers, which ranked third, fourth and fifth for both small and medium farmers. Poor facilities for genetic improvement and research in farms was ranked the lowest (mean score - 33.65) by small farmers whereas, restrictions in providing license for brooders import was considered the least important constraint (mean score - 33.44) by medium farmers.

Table 3 depicts the other constraints that are faced by the ornamental fish farmers. From the study, it was found that a gap exists between farmers and technical institutions in transfer of advanced technologies of ornamental culture practices. It was reported as the top most constraint by both small and medium farmers with a mean score of 59.42 and 61.39 respectively. The next rank was found to be predation of ornamental fishes by birds and animals. Other constraints reported by farmers were pilferage, collection of live feed from far areas and inadequate supply of water and farming area.

In the present study, it was found that the revenue loss in both small and medium farms were mainly due to mortality of fishes. Estimation regarding loss due to different mortality factors showed that $80 \%$ mortality in fish was due to diseases which were caused by environmental factors (47\%) and poor management practices $(33 \%)$. The remaining mortality was because of transportation (11\%) and handling (9\%) as shown in Fig. 1. The loss $(80 \%)$ due to disease incidence in fish was lower than that reported $(90 \%)$ by Umamaheswari (2003). The major reason for the mortality of fish could be lack of knowledge on scientific farming methods and the same was reported by Verma (2003), who reported that $48 \%$ of fisherwomen lacked skill and knowledge on scientific practices of aquaculture in Odisha State. Water quality 
Table 1. Analysis of production constraints encountered in ornamental fish farming

\begin{tabular}{|c|c|c|c|c|c|c|}
\hline \multirow{2}{*}{ Production constraints } & \multicolumn{3}{|c|}{ Small farmers $(n=26)$} & \multicolumn{3}{|c|}{ Medium farmers $(\mathrm{n}=18)$} \\
\hline & $\begin{array}{l}\text { Sum } \\
\text { of scores }\end{array}$ & $\begin{array}{l}\text { Mean } \\
\text { score }\end{array}$ & $\begin{array}{l}\text { Order of } \\
\text { merit }\end{array}$ & $\begin{array}{l}\text { Sum } \\
\text { of scores }\end{array}$ & $\begin{array}{l}\text { Mean } \\
\text { score }\end{array}$ & $\begin{array}{l}\text { Order of } \\
\text { merit }\end{array}$ \\
\hline $\begin{array}{l}\text { Disease outbreak due to } \\
\text { environmental factors }\end{array}$ & 1929 & 74.19 & $\mathrm{I}$ & 1367 & 75.94 & $\mathrm{I}$ \\
\hline $\begin{array}{l}\text { Disease outbreak due to poor } \\
\text { management practices }\end{array}$ & 1806 & 69.46 & II & 1220 & 67.78 & II \\
\hline $\begin{array}{l}\text { Absence of technically skilled } \\
\text { personnel and labour }\end{array}$ & 1238 & 47.62 & IV & 912 & 50.67 & IV \\
\hline Risks in breeding egg layers & 1213 & 46.65 & $\mathrm{~V}$ & 833 & 46.28 & $\mathrm{~V}$ \\
\hline $\begin{array}{l}\text { Poor facilities for genetic improvement } \\
\text { and research in farms }\end{array}$ & 875 & 33.65 & IX & 647 & 35.94 & VIII \\
\hline Lack of brood fish resource & 1064 & 40.92 & VI & 735 & 40.83 & VII \\
\hline $\begin{array}{l}\text { Restrictions in providing license } \\
\text { for brooders import }\end{array}$ & 938 & 36.08 & VIII & 602 & 33.44 & IX \\
\hline Mortality during transport & 1002 & 38.54 & VII & 829 & 46.06 & VI \\
\hline $\begin{array}{l}\text { Insufficient credit facility from } \\
\text { institutional sources }\end{array}$ & 1347 & 51.81 & III & 983 & 54.61 & III \\
\hline
\end{tabular}

Table 2. Analysis of marketing constraints encountered in ornamental fish farming

\begin{tabular}{|c|c|c|c|c|c|c|}
\hline \multirow{2}{*}{ Marketing constraints } & \multicolumn{3}{|c|}{ Small farmers $(\mathrm{n}=26)$} & \multicolumn{3}{|c|}{ Medium farmers $(\mathrm{n}=18)$} \\
\hline & $\begin{array}{l}\text { Sum of } \\
\text { scores }\end{array}$ & $\begin{array}{l}\text { Mean } \\
\text { score }\end{array}$ & $\begin{array}{l}\text { Order of } \\
\text { merit }\end{array}$ & $\begin{array}{l}\text { Sum of } \\
\text { scores }\end{array}$ & $\begin{array}{l}\text { Mean } \\
\text { score }\end{array}$ & $\begin{array}{l}\text { Order of } \\
\text { merit }\end{array}$ \\
\hline High competition & 1700 & 65.38 & I & 1125 & 62.50 & I \\
\hline Uncertainty in demand & 1485 & 57.12 & II & 930 & 51.67 & II \\
\hline Absence of market by local administration & 1100 & 42.31 & IV & 855 & 47.50 & III \\
\hline $\begin{array}{l}\text { Absence of marketing organisation for } \\
\text { development }\end{array}$ & 980 & 37.69 & $\mathrm{~V}$ & 820 & 45.56 & IV \\
\hline Inadequate facilities for marketing & 1180 & 45.38 & III & 815 & 45.28 & $\mathrm{~V}$ \\
\hline
\end{tabular}

Table 3. Analysis of other constraints encountered in ornamental fish farming

\begin{tabular}{|c|c|c|c|c|c|c|}
\hline \multirow{2}{*}{ Other constraints } & \multicolumn{3}{|c|}{ Small farmers $(n=26)$} & \multicolumn{3}{|c|}{ Medium farmers $(\mathrm{n}=18)$} \\
\hline & $\begin{array}{l}\text { Sum of } \\
\text { scores }\end{array}$ & $\begin{array}{l}\text { Mean } \\
\text { score }\end{array}$ & $\begin{array}{l}\text { Order of } \\
\text { merit }\end{array}$ & $\begin{array}{l}\text { Sum of } \\
\text { scores }\end{array}$ & $\begin{array}{l}\text { Mean } \\
\text { score }\end{array}$ & $\begin{array}{l}\text { Order of } \\
\text { merit }\end{array}$ \\
\hline Pilferage & 1170 & 45.00 & IV & 872 & 48.44 & III \\
\hline $\begin{array}{l}\text { Predation of ornamental fishes } \\
\text { by birds and animals }\end{array}$ & 1385 & 53.27 & II & 880 & 48.89 & II \\
\hline $\begin{array}{l}\text { Existence of gap in acquiring advanced } \\
\text { technologies on farming practices }\end{array}$ & 1545 & 59.42 & I & 1105 & 61.39 & I \\
\hline Live feed collection from far areas & 1245 & 47.88 & III & 810 & 45.00 & $\mathrm{~V}$ \\
\hline Inadequate water supply and farming area & 1145 & 44.04 & V & 845 & 46.94 & IV \\
\hline
\end{tabular}

management is the main factor for the survival of young ones. Swain et al. (2003) reported that lack of scientific knowledge on water quality management for rearing and breeding of ornamental fishes as a major constraint in ornamental fish farming.

The percentage distribution of revenue loss for all the farms is given in Table 4 . The total and mean annual revenue loss due to disease outbreak as reported by both small and medium farmers were documented and the results are summarised in Table 5.

Out of the 26 small farms surveyed, 6 farms (23.08\%) showed revenue loss between ₹5001 to 10,000 per year (Table 4). Twelve farms (46.15\%) reported loss in the range of ₹ 10,001 to 15,000 per year. In small farm units, the fish 


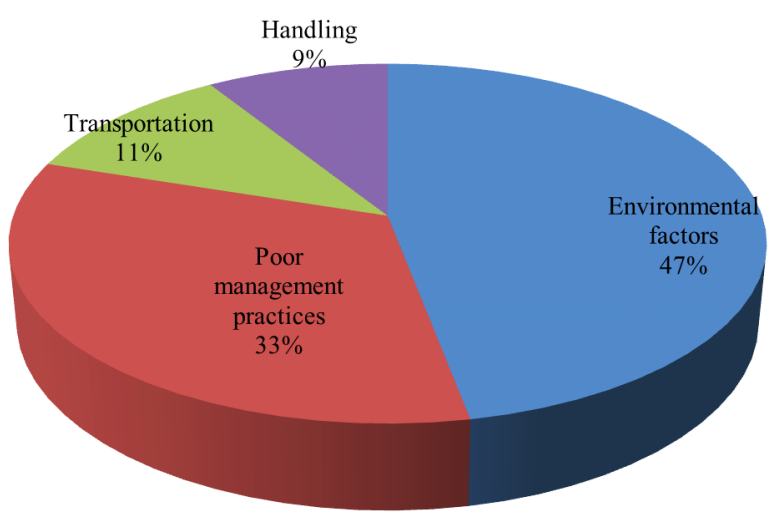

Fig. 1. Mortality of ornamental fishes due to various factors

Table 4. Percentage distribution of revenue loss due to disease in farms

\begin{tabular}{llllll}
\hline Loss range $(₹)$ & \multicolumn{2}{c}{ Small farms } & & \multicolumn{2}{c}{ Medium farms } \\
\cline { 2 - 3 } & No. & $(\%)$ & & No. & $(\%)$ \\
\hline $5001-10000$ & 6 & 23.08 & & 7 & 38.89 \\
$10001-15000$ & 12 & 46.15 & & 5 & 27.78 \\
$15001-20000$ & 8 & 30.77 & & 6 & 33.33 \\
Total & 26 & 100.00 & & 18 & 100.00 \\
\hline
\end{tabular}

In medium farms, the minimum and maximum annual revenue loss recorded was ₹15,220 and ₹22,000 respectively (Table 4). Out of the 18 medium farms surveyed, 7 farms (38.89\%) reported loss with a range between ₹5,001 to 10,000 and five farms $(27.78 \%)$ incurred a revenue loss ranging between ₹10,001 and 15,000. The variability of revenue loss was due to variable management factors and the type of fish handled and the area in which the farms are located. Similar variation in loss with respect to location, management and size of farm was reported by Faruk et al. (2004). The farmers handle low and medium value fishes like gold fish, koi, guppy, barb and cichlids where the revenue loss was between ₹ 15,001 and 20,000. The medium farms which experienced high revenue loss of above ₹20,000, handle fishes of high value and imported varieties like flower horn and arowana varieties. Hence, the death of highly priced fish in addition to other varieties reduced revenue and increased the loss. It was also observed that, in some of the medium farms, even after proper management, disease occurrence occurred which might be due to the transfer of infected seedlings.

The actual profit for all the farms was calculated by finding out the difference between the total returns and total

Table 5. Estimation of revenue loss due to disease incidence in ornamental fish farms (₹ lakhs)

\begin{tabular}{lllllllll}
\hline Particulars & & TC & TR & AP & MC+TMC & STF & EP & RLD \\
\hline Small farms & Total & 30.86 & 39.68 & 8.81 & 0.81 & 4.08 & 12.11 & 32.94 \\
& Mean & 1.18 & 15.26 & 0.34 & 0.03 & 0.16 & 0.46 & 0.13 \\
\hline Medium farms & Total & 127.30 & 150.39 & 230.81 & 2.23 & 43.52 & 25.20 & 21.19 \\
Mean & & 7.07 & 8.35 & 12.82 & 0.12 & 0.24 & 1.40 & 0.12 \\
\hline
\end{tabular}

TC - Total cost, TR - Total revenue, AP - Actual profit, MC - Maintenance cost, TMC - Treatment cost, STF - Sale value of treated fish, EP - Expected profit, RLD - Revenue loss due to disease incidence

tanks are subjected to varying environmental conditions and also poor management. Hence, the disease incidence is at a higher level due to poor understanding of diseases, making the treatment complicated and leading to death of fish and in turn revenue loss. Asaduzzaman Sarkar et al. (2006) reported lack of technical knowledge of farmers regarding farm management as the main reason for disease occurrence and revenue loss. The small scale farmers culture only low and medium value fishes like live bearers, gold, koi and to certain extent cichlids and the revenue loss due to disease incidence was found to be around $50 \%$. Observation on small farms revealed that majority of the fish mortality and disease incidence were due to poor knowledge of the farmers regarding water quality, feeding and disease management, which was also reported by Elamparithy (1999). The variation in locality, season and infection also plays a major role. Banu et al. (2004), reported that disease prevalence varied with season and species of fish. Observations during the present study also clearly indicate that disease prevalence varies with seasons, locality and the type of fish. cost incurred. The study clearly indicated that the mean annual actual profit was higher for medium farms (₹1.28 lakhs) when compared to small farms (₹0.34 lakhs) as shown in Table 4. The expected annual return was calculated by determining the difference between the cost incurred towards maintenance and treatment of diseased fishes and the sale value of treated/recovered fishes at prevailing market price.

The mean annual maintenance and treatment cost incurred by small farms was ₹0.03 lakhs, whereas for medium farms, it was ₹0.12 lakhs. In the same way, the mean annual expected profit margin was on the higher side for medium farms (₹1.45 lakhs) as compared to the small farms (₹0.47 lakhs). On the contrary, the mean annual revenue loss due to disease was estimated to be ₹0.13 lakhs for small farms, which was found to be greater than that for the medium farms (₹0.11 lakhs). The small ornamental fish farms in Madurai District were found to be struggling to generate more revenue as they face serious disease outbreaks in farms, while many 
of the medium farms were able to generate more revenue as they have established biosecurity systems.

The present study on the economics of production of ornamental fishes in Madurai District revealed that the income loss due to disease prevalence was higher in small farms. Variation in revenue loss was found to depend on factors like farm size, type and size of ornamental fish cultured, establishment of biosecurity systems, technical knowledge in ornamental fish farming methods, disease diagnostics, management practices as well as investment costs. The constraints faced by the small and medium ornamental fish farmers were found numerous and need to be effectively addressed by the government agencies and policy makers, particularly for dissemination of advanced technologies, establishment of brood bank for ornamental fishes and providing license for importing brooders as expressed by the ornamental fish farmers.

\section{References}

Asaduzzaman Sarkar, Atahurul Hnq Chowdhry and Yoshihito Itohara 2006. Entrepreneurship barriers of pond fish culture in Bangladesh - A case study from Mymensingh District. J. Social Sci., 2(3) : 68-73.

Banu, A. N. H., Hossain, M. A. and Khan, M. H. 1993. Investigation into the occurrence of parasites in carps, catfish and tilapia. Progress. Agric., 4: 11-16.

Das, R. C. and Sinha, A. 2003. Ornamental fish trade in India. Fishing chimes, 23(2): 16-18.

Dey, V. K. 2012. The Indian ornamental fish sector-developing strategies to reach the heights. INFOFISH Int., 5: 30-33.

Elamparithy, B. 1999. Prospects and problems in ornamental fish culture in India. National seminar on development and transfer of fisheries technologies, Fisheries College and Research Institute, Thoothukudi, p. 29-31.

Faruk, M. A. R., Sarkar, M. M. R., Alam, M. J. and Kabir, M. B. 2004. Economic loss from fish diseases on rural freshwater aquaculture of Bangladesh. Pak. J. Biol. Sci., 7(12): 2086-2091.

Ghosh, A., Mahapatra, B. K. and Datta, N. C. 2003a. Ornamental fish farming - Successful small scale aqua business in India. Aquac. Asia, 8(3): 14-16.

Ghosh, A., Mahapatra, B. K. and Datta, N. C. 2003b. Haibagan haat, Kolkata - The largest wholesale ornamental fish market of Eastern India. Fishing Chimes, 23(1): 166-168.

Mukherjee, M., Chattopadyay, M., Datta, S. K. and Biswas, S. 2000. Problems and prospects of aquarium fish trade in West Bengal. Fishing Chimes, 20(1): 90-93.

NABARD 2007. Guidelines: Model bankable projects in Fisheries. National bank for agriculture and Rural Development (NABARD), India. http://www.nabard.orgmodelbankprojects/ fish_ornamental_fish.asp.

Prathvi Rani, Sheela Immanuel, Ananthan, P. S., Ojha, S. N., Kumar, N. R. and Krishna, M. 2013. Export performance of Indian ornamental fish - an analysis of growth, destination and diversity. Indian J. Fish., 60(3): 81-86.

Sahu, B. B. and Mohanty, S. 2000. Quality control of ornamental fish for export. Compendium of lectures on ornamental fish breeding and culture, Central Institue of Freshwater Aquaculture, Bhuvaneswar, p: 55-62.

Shaleesha, A. and Stanley, V. A. 2001. Breeding of ornamental fish - An underdeveloped enterprise. Fishing Chimes, 25(6): 9-18.

Singh, A. K. and Ahmed, S. H. 2005. Ornamental fish culture in Bihar: Prospects as a cottage industry. Fishing Chimes, 25(6): 9-18.

Swain, S. K., Tena, T. K. and Ayyappan, S. 2003. Prospects of export oriented freshwater ornamental fish culture in India. Fishing chimes, 22 (10 \&11): 111-113.

Umamaheswari, T. 2003. Application of costing techniques in aquariculture. M. F. Sc. Thesis, Tamil Nadu Veterinary and Animal Sciences University, Chennai, 70 pp.

Verma, J. P. 2003. Effectiveness of training programmes for farmers. Kurukshetra, 5(3): 36-37. 